\title{
Utilization of the phyphox application (physical phone experiment) to calculate the moment of inertia of hollow cylinders
}

\author{
Sabila Yasaroh $^{1}$, Heru Kuswanto ${ }^{2}$, Desi Ramadhanti ${ }^{3}$, Aisha Azalia ${ }^{4}$, Hestiana $^{5^{*}}$ \\ ${ }^{1-5}$ Master Program of Science Education, FMIPA, Yogyakarta State University, Indonesia.
}

*Corresponding Address: sabilayasaroh.2020@student.uny.ac.id

\begin{tabular}{|c|c|}
\hline Article Info & ABSTRACT \\
\hline $\begin{array}{l}\text { Article history: } \\
\text { Received: June } 20^{\text {th }}, 2021 \\
\text { Accepted: October } 18^{\text {th }}, 2021 \\
\text { Published: October XX, } 2021\end{array}$ & $\begin{array}{l}\text { Experiments have been carried out on determining the value of the moment } \\
\text { of inertia of a hollow cylinder. This study aims to analyze the value of the } \\
\text { moment of inertia with variations in the radius of the hollow cylinder using } \\
\text { the Phyphox Application (Physical Phone Experiment). This research is } \\
\text { experimental. The tools and material used are a } 1 \text {-meter longboard, three } \\
\text { hollow cylinders with different radius sizes but the same mass, smartphone, } \\
\text { laptop, caliper, and balance. The experiment of rolling motion on a hollow } \\
\text { cylinder on an inclined plane is assisted by data processing in a Phyphox } \\
\text { application. From the experiment, the result of the moment of inertia value } \\
\text { from data processing is } 4.89 \mathrm{x} 10^{-4} \mathrm{~kg} . \mathrm{m}^{2}, 9.82 \times 10^{-4} \mathrm{~kg} \cdot \mathrm{m}^{2}, 12.4 \mathrm{x} 10^{-} \\
{ }^{4} \mathrm{~kg} \text {. } \mathrm{m}^{2} \text {. This research can be used as a teacher reference in teaching the topic } \\
\text { of moments of inertia in physics learning at school. This is highly } \\
\text { recommended for distance learning during the pandemic so that mastery of } \\
\text { concepts is maximized. Further research is suggested that it can be tried to } \\
\text { use other materials with other types of rigid bodies to find the moment of } \\
\text { inertia. Further references on digital application media to assist learning are } \\
\text { also needed considering the dynamic development of technology. }\end{array}$ \\
\hline
\end{tabular}

(C) 2021 Physics Education Department, UIN Raden Intan Lampung, Indonesia.

\section{INTRODUCTION}

Cylindrical motion down an inclined plane is an example of rigid body dynamics in physics concepts studied in high school (Saputra \& Pramudya, 2019). The dynamic motion of a cylinder that rolls on an inclined plane are an exciting topic. The rolling motion is found in a landslide and other rolling phenomena (Ariefka \& Pramudya, 2019). An example of rigid body dynamics is the movement of a rigid ball down an inclined plane. In this example, the ball undergoes rotational and translational motion (Riswanto \& Suharno, 2014).
The moment of inertia is one factor that affects an object's rotational motion (Mulhayatiah et al., 2018; Ariefka \& Pramudya, 2019). The moment of inertia is a derived quantity that is affected by the radius of an object. If an object has a radius, then the object will have an angular velocity and rotate (Riswanto \& Suharno, 2014; Jumini \& Muhlisoh, 2013). In the analogy of translational motion, rotation measures are angular position, angular velocity, and angular acceleration (Schmelzbach et al., 2018). If the moment of inertia is significant, the object will be challenging to 
rotate from rest and more difficult to stop when in a rotating state (Rivia et al., 2016). The moment of inertia of a rigid body can be determined by its mass and physical dimensions, both mathematically and experimentally (Hara et al., 2012).

Experiments rolling cylinders on an inclined plane are carried out using smartphones as science and technology advance. Smartphones play a crucial role in increasing students' interest in physical concepts and the motivation to study them further, facilitating various calculations and measurements, reducing data acquisition, and time doing experiments (Nurfadilah et al., 2019). Currently, the most popular gadget owned by about $93 \%$ of students is a smartphone (Olga, 2017), which creates conditions for access to educational programs, scientific materials, and mobile applications for field experiments.

Mobile applications assist several studies on experimental physics. For example, research conducted by Yusuf (2015) by measuring the moment coefficient of inertia of solid balls using Tracker software and researching the moment coefficients of inertia of hollow cylinders (PVC pipes) and solid cylinders (coins) using Logger Pro software. Another researcher, Vieyra et al., (2015), investigated the relationship between action force and body acceleration using the Physics Toolbox Sensor Suite. Then Parsons (2016) and Alqahtani (2017) also research mobile applications in university education and future specialist training. There is also a study on the development of mobile applications for processing data from smartphone sensors and several examples of techniques for using the Physics Toolbox Sensor Suite and Phyphox conducted by Sukariasih et al. (2019). Lastly, the issue of implementing and using mobile devices in physics teaching was investigated by Kaps \& Stallmach (2020).
An essential role in research on smartphone use is played by dedicated mobile applications, which have transformed from digital sensors to open platforms that process and analyze experimental data over the years. However, this research shows that the mobile analysis explained from scientific and pedagogical sources shows that it is now very relevant to research and systematize the application's method as a practical tool for educational research during the study of physics. Instrumental innovation has been created by smartphones containing sets of sensors and related software; they are suitable for fullsized academic research, particularly for distance learning in times of pandemic or supporting learning innovation in the digital age.

One of the mobile smartphone applications used in physics learning is Phyphox. Phyphox has been used by Pierratos \& Polatoglou (2020) to study uniforms using an optical stopwatch based on the action of smartphone photosensors. This app is free to download and has so many features that are very helpful in this time of distance learning (Carroll \& Lincoln, 2020). Phyphox works for both Android and Apple phones, and there are plenty of experiments already available for it online and built-in (Phyphox, 2020).

The Phyphox app takes advantage of the sensors already on the smartphone and generates data and graphs in real-time. This is unusual for a mobile physics app; experiments are usually available and very numerous (Fig. 1). Phyphox has been cited as beneficial in several of these journal articles (Sukariasih et al., 2019; Stampfer et al., 2020; Kaps \& Stallmach, 2020). Phyphox is open source, and its applications are not limited to the experiments it contains. Students and teachers can be creative and inventive. This application is even compatible with Arduino can also be 
connected remotely to a $\mathrm{PC}$ to provide live data, so it is flexible, not stand-alone. It can be adapted to needs and all conditions (Carroll \& Lincoln, 2020). There are several simulations in the Phyphox application, so one of them is the Roll simulation. Roll simulation tracks speed using a gyroscope to determine angular velocity (Nisa et al., 2019). The angular velocity data generated from Phyphox will later be processed to find the moment of inertia value.

Based on experience in the field, the problem that occurs to most high school students when learning the moment of inertia is that it is not easy to distinguish constants and lack of understanding of concepts. To determine the value of the moment of inertia and include the factors that affect the object when it rolls, it can be seen from the object's motion review processing. However, the motion of the object must be constant. This is intended so that the resulting data has a high level of accuracy and precision (Setyawan et al., 2017). Some of these obstacles can be minimized using Phyphox. During the experiment, Phyphox also anticipated several risks in direct practice in the lab, such as faulty equipment, tools that are prone to damage, and cleanliness that must be maintained; which these things can cause experimental data to be less accurate (Nisa et al., 2019). There has been no experiment to determine the moment of inertia of a hollow cylinder using Phyphox in previous studies, either using a logger pro (Yusuf, 2015) or other applications that tend to be complicated. This study uses Phyphox, which is considered more accurate and easy to use for high school students. Therefore, the purpose of this study is to analyze the value of the moment of inertia with variations in the radius of a hollow cylinder using the Phyphox and to demonstrate a suitable mobile application technology to do effective educational research using actual experiments so that students understand better about the moment of inertia and its constants because they can learn directly from experiments, not just reading and memorizing material.

\section{METHODS}

This study uses a direct experimental approach assisted by the Phyphox. The speed generated by each track is not constant. This is due to the rolling motion on an inclined plane $\left(15^{\circ}\right)$ accelerating the object's speed. Therefore, the translational motion of a solid cylinder applies with the general equation:

$$
\begin{gathered}
K E=K E \text { translation }+K E \text { rotation } \\
K E=1 / 2 m v 2+1 / 2 I 0 \omega 2
\end{gathered}
$$

It proves the theory that velocity represents the translational motion of a solid cylinder (Riswanto \& Suharno, 2014). Figure 1 shows that the home screen of the Phyphox indicates that there are many experiments and data sources that are available for creative students to try out.

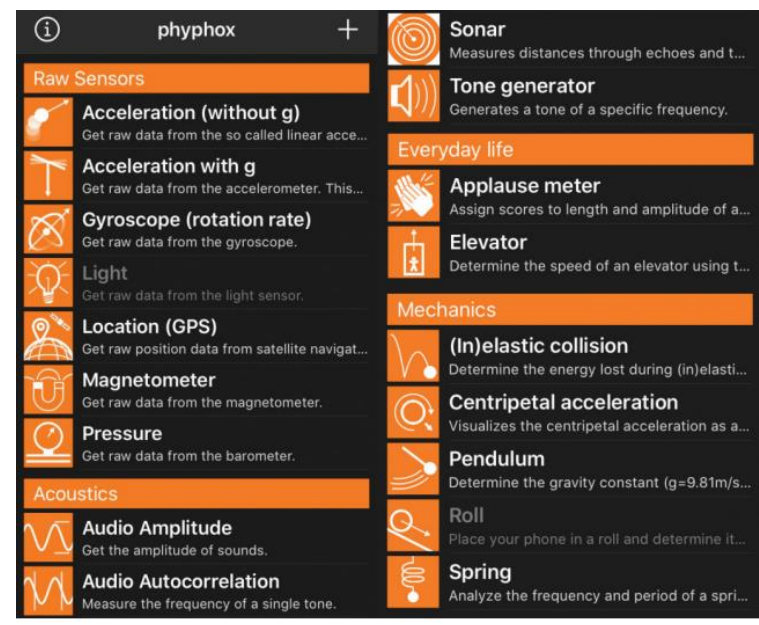

Figure. 1. The Home Screen of the Phyphox App

This research was conducted at the practitioner's house in May 2021. The research subjects studied were solid cylinders with variations in the radius of 4 $\mathrm{cm}, 5 \mathrm{~cm}$, and $6 \mathrm{~cm}$. The three research subjects can be seen in Figure 2, and a 
schematic of the research procedure carried out on an inclined plane can be seen in Figure 3.

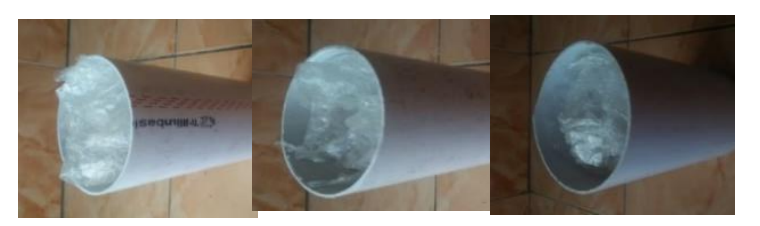

(a)

\begin{abstract}
(b)
\end{abstract}
(c)

Figure 2. Research Subjects studied were solid

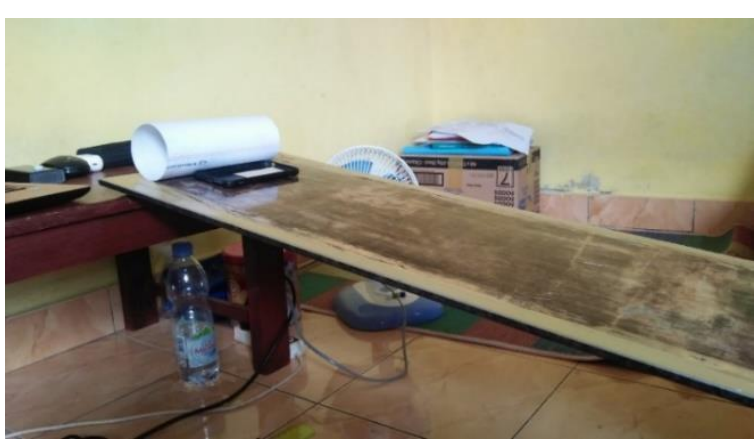

Figure 3. Schematic of Research Procedures cylinders with a radius of $4 \mathrm{~cm}(\mathrm{a}), 5 \mathrm{~cm}$ (b),

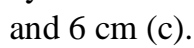

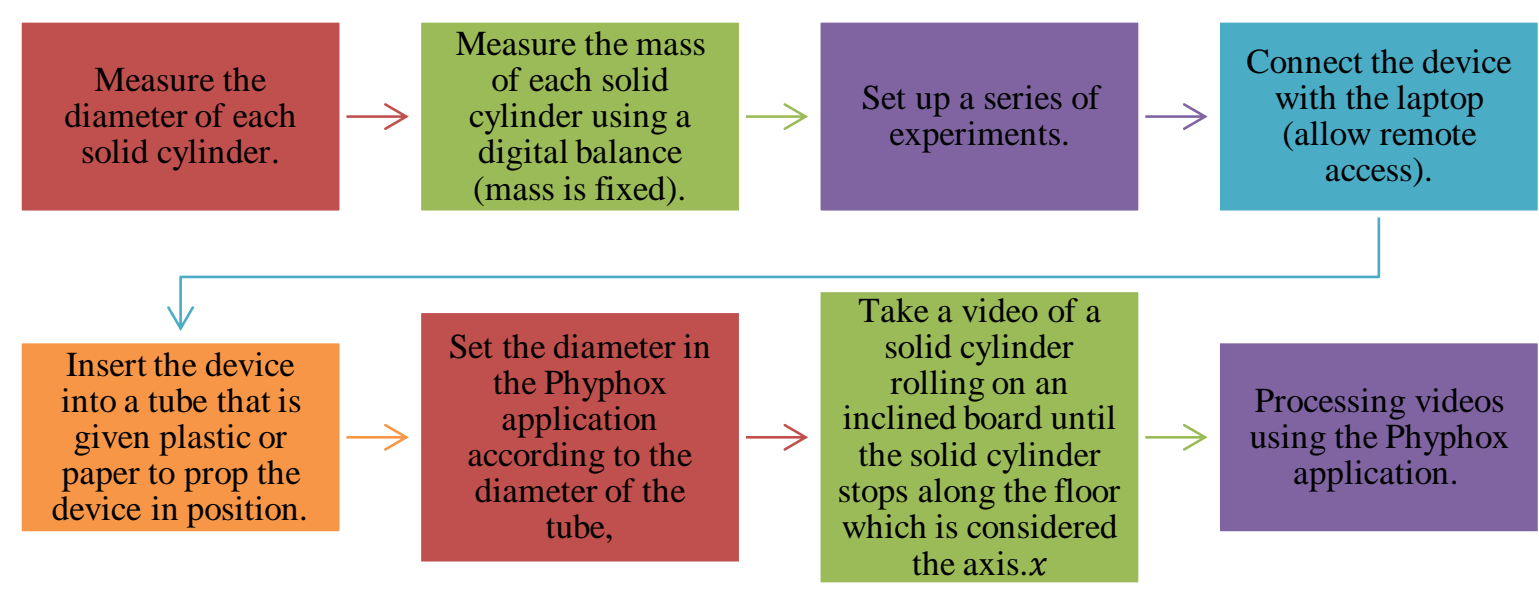

Figure 4. Research Procedures

The procedure of this research shows in Fig 4. The data obtained from this study are the mass of a solid cylinder that is fixed, the radius of a solid cylinder, time, linear velocity, and angular velocity when rolling obtained from the Phyphox application.

According to Jati (2013), the moment of inertia in a continuous rigid body is written:

$$
I=\int r^{2} d m
$$

then through the equation:

$$
I=\sum m R^{2}
$$

So, the angular momentum equation is:

$$
\begin{aligned}
& L=I \omega \\
& L=m v r
\end{aligned}
$$

From the two equations above, the next equation is obtained, namely:

$$
m v r=I \omega
$$

Based on equation (6), the moment of inertia can be calculated as follows:

$$
I=\frac{m v r}{\omega}
$$

Where $m$ is the mass of the object $(\mathrm{kg}), v$ is the linear velocity $(\mathrm{m} / \mathrm{s}), r$ is the radius of the cylinder $(\mathrm{m}), \omega$ is the angular velocity $(\mathrm{rad} / \mathrm{s})$, and I the moment of inertia $\left(\mathrm{kgm}^{2}\right)$.

\section{RESULTS AND DISCUSSION}

Based on measurements using a digital balance on each solid cylinder consisting of a $0.13 \mathrm{~kg}$ smartphone and $0.18 \mathrm{~kg}$ pipe, the mass as a fixed variable is $0.31 \mathrm{~kg}$. Roll simulation was carried out for data collection with a radius of $4 \mathrm{~cm} 3$ times, as presented in Figure 5. 

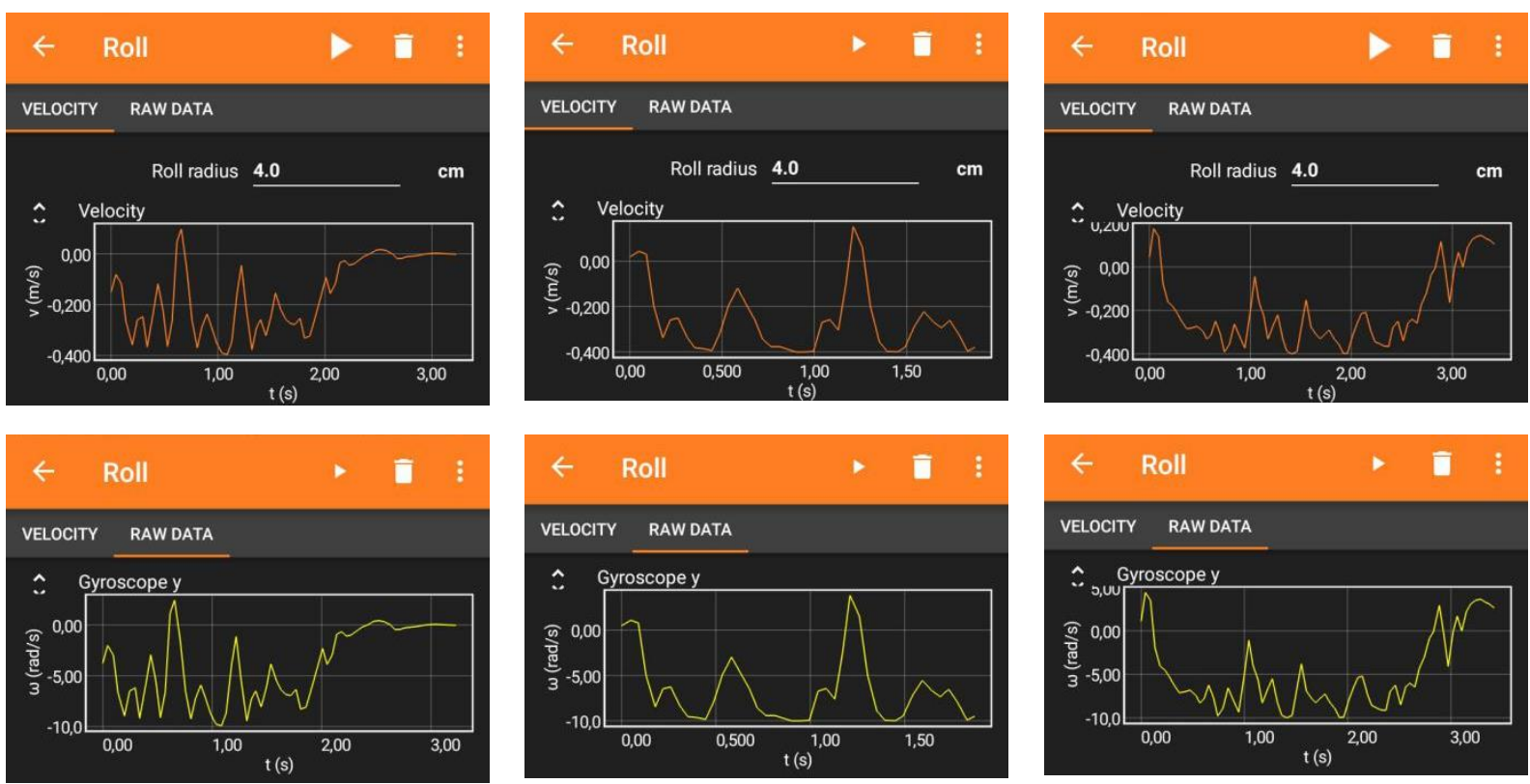

Figure 5. Simulation Result Data 1, 2, and 3

After three repetitions on a $4 \mathrm{~cm}$ diameter pipe, the Phyphox tracking data is obtained in graphical form, as shown in Figure 5. This data is then exported into Ms. Excel, and the average is sought. Obtained an average velocity $(v)$ is $0.06 \mathrm{~m} / \mathrm{s}, 0.01 \mathrm{~m} / \mathrm{s}$, and $0.11 \mathrm{~m} / \mathrm{s}$. while the angular velocity $(\omega)$ is $0.152 \mathrm{rad} / \mathrm{s}, 0.42 \mathrm{rad} / \mathrm{s}$, and $2.93 \mathrm{rad} / \mathrm{s}$.

Followed by data collection 3 (three) times at a radius of $5 \mathrm{~cm}$, the data results are presented in Figure 6.
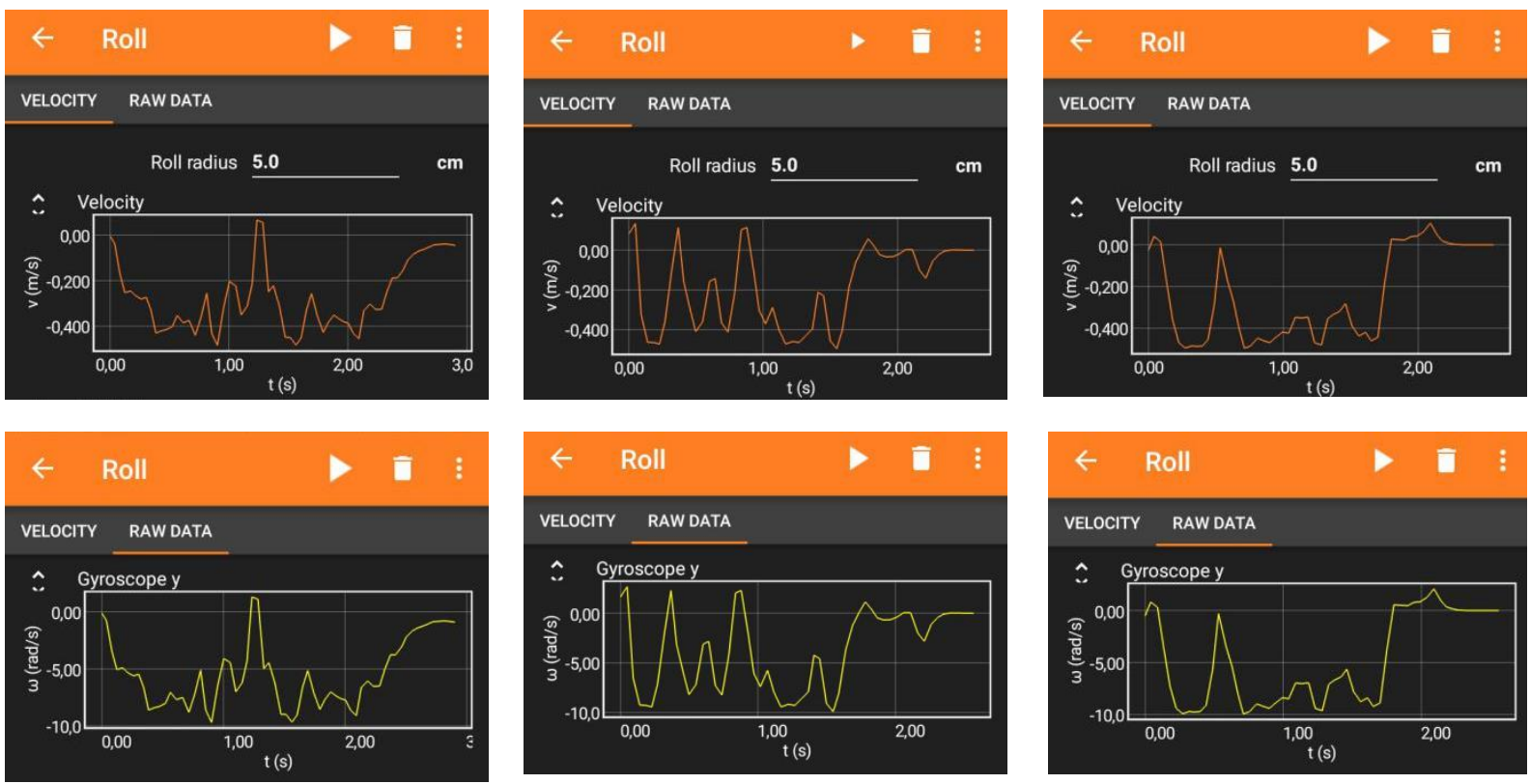

Figure 6. Simulation Result Data 4, 5, and 6

After three repetitions on a $5 \mathrm{~cm}$ diameter pipe, the Phyphox tracking data is obtained in graphical form, as shown in Figure 6. This data is then exported into excel, and the 
average is sought. obtained an average speed of $0.06 \mathrm{~m} / \mathrm{s}, 0.02 \mathrm{~m} / \mathrm{s}$, and $0.04 \mathrm{~m} / \mathrm{s}$. while the angular velocity is $1.21 \mathrm{rad} / \mathrm{s}, 0.54$ $\mathrm{rad} / \mathrm{s}$, and $0.91 \mathrm{rad} / \mathrm{s}$.
The last data collection with a radius of $6 \mathrm{~cm}$ is the same as the previous data collection, which was carried out 3 (three) times. The data results are shown in Figure 7.
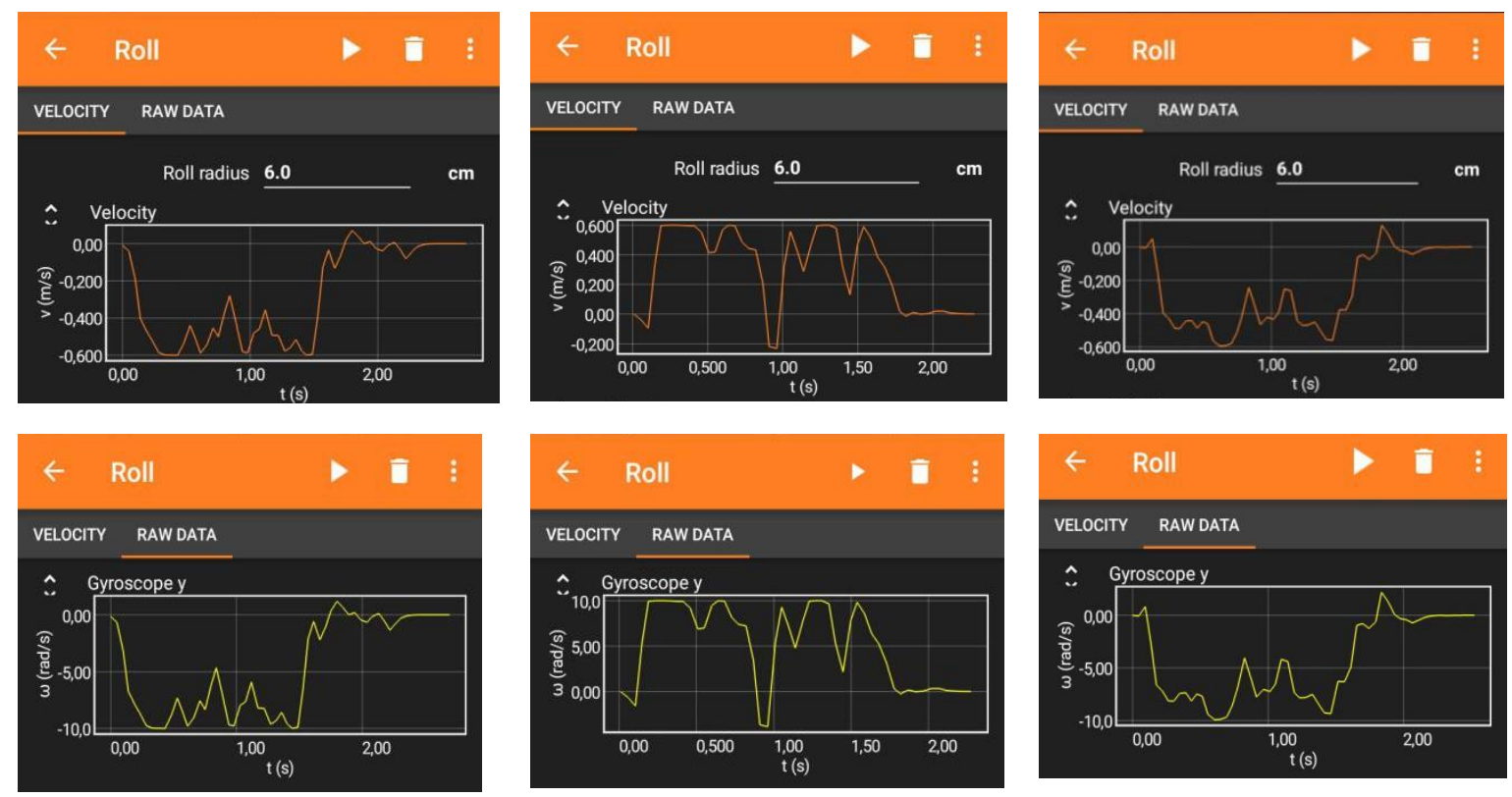

Figure 7. Simulation Result Data 7, 8, and 9

After three repetitions on a $6 \mathrm{~cm}$ diameter pipe, the Phyphox tracking data is obtained in graphical form, as shown in Figure 7. This data is then exported into excel, and the average is sought. obtained an average speed of $0.01 \mathrm{~m} / \mathrm{s}, 0.04 \mathrm{~m} / \mathrm{s}$, and $0.37 \mathrm{~m} / \mathrm{s}$. while the angular velocity is $0.21 \mathrm{rad} / \mathrm{s}, 0.72$ $\mathrm{rad} / \mathrm{s}$, and $6.22 \mathrm{rad} / \mathrm{s}$.
After obtaining data from each simulation, then the moment of inertia is calculated. Then the results are compared with the manual practicum, which is calculated using the formula for the moment of inertia of a solid cylinder, namely: $I=$ $\sum m R^{2}$. Here is the tabulation of the data:

Table 1. Moment of Inertia Calculation Data

\begin{tabular}{|c|c|c|c|c|c|c|c|c|}
\hline \multirow[b]{2}{*}{ No } & \multirow[b]{2}{*}{$\overline{\boldsymbol{r}}(\mathbf{m})$} & \multirow{2}{*}{$\underset{(\mathbf{m g})}{\bar{m}}$} & \multirow[b]{2}{*}{$\bar{v}(\mathbf{m} / \mathbf{s})$} & \multirow{2}{*}{$\begin{array}{c}\overline{\boldsymbol{\omega}} \\
(\mathrm{rad} / \mathbf{s})\end{array}$} & \multicolumn{2}{|c|}{ Phypox Assisted } & \multicolumn{2}{|c|}{ Manual Practicum } \\
\hline & & & & & $\bar{I} \pm \Delta \bar{I}\left(\times 10^{-4}\right.$ kg. $\left.\mathbf{m}^{2}\right)$ & $\mathrm{RE}(\%)$ & $\begin{array}{c}\bar{I} \pm \Delta \bar{I}(\times \\
\left.\mathbf{1 0}^{-4} \mathbf{k g} \cdot \mathbf{m}^{2}\right)\end{array}$ & $\begin{array}{l}\text { RE } \\
(\%)\end{array}$ \\
\hline 1. & 0.04 & 0.31 & 0.06 & 1.62 & $4.17 \pm 2.86 \times 10^{-9}$ & $0.69 \times 10^{-9}$ & $4.96 \pm 0.00$ & 0 \\
\hline 2. & 0.05 & 0.31 & 0.07 & 1.57 & $6.75 \pm 6.48 \times 10^{-9}$ & $0.96 \times 10^{-9}$ & $7.76 \pm 0.00$ & 0 \\
\hline 3. & 0.06 & 0.31 & 0.14 & 2.38 & $10.09 \pm 2.85 \times 10^{-9}$ & $0.28 \times 10^{-9}$ & $11.16 \pm 0.00$ & 0 \\
\hline
\end{tabular}

Based on the data tabulation (Table 1), the researcher then made a graph to show the differences in manual and Phyphox- assisted practicum analysis results (see Figure 8). 
Graph of the Moment of Inertia of Manual and PhyphoxAssisted Practicum

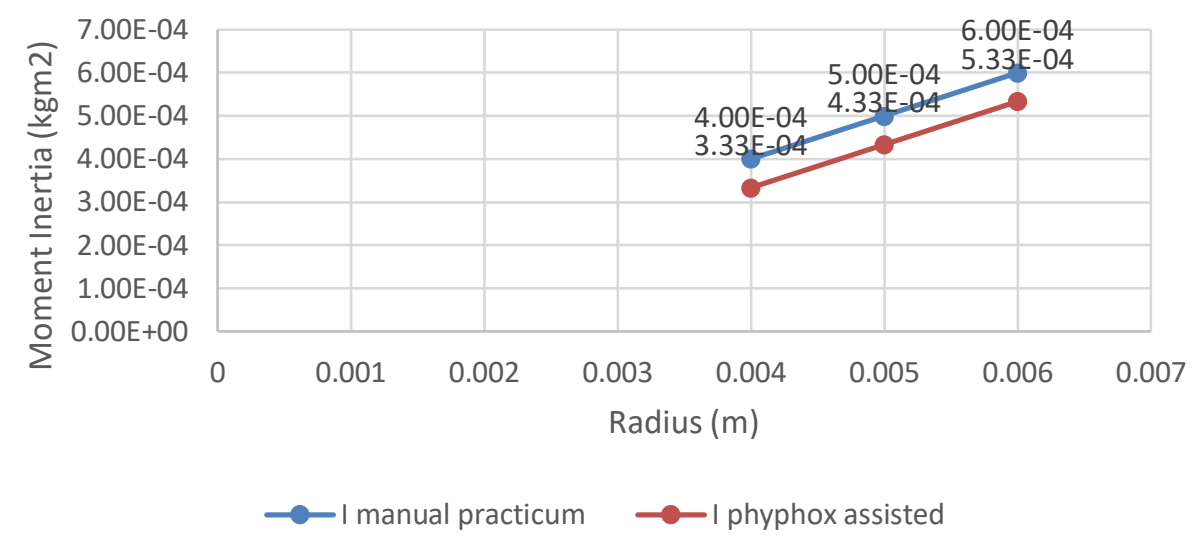

Figure 8. Graph of the Moment of Inertia of Manual and Phyphox-Assisted Practicum.

Based on the graph in Figure 8, it can be seen that the value of the moment of inertia is linear with the pipe diameter. The moment of inertia of the manual practicum results tends to be greater than the moment of inertia assisted by Phyphox. This can be caused by the value of $I$ for manual practicum using the multiplication between the mass and the square of the radius of the pipe. At the same time, $I$ for the Phyphox load, $v$ speed data is taken from tracking using a more accurate smartphone sensor.

In this experiment, the relative error of $I$ using Phyphox is also minimal, ranging from $0,28 \times 10^{-9} \%$ up to $0,96 \times 10^{-9} \%$ smaller compared to the relative error results of the manual practicum, which is worth 0\%. So, it can be said that the Phyphoxassisted $I$ results are more accurate because the smaller the percentage of measurement error, the more precise the result data (Respati, \& Rahardjo, 2017).

Past research that underlies this research includes research on finding angular velocity and velocity with Phyphox media on rolls in physics learning technology (Nisa et al., 2019) which is then used to calculate the value of the moment of inertia, determine the moment of inertia of solid cylindrical objects with integral and tracker
(Chusni et al., 2018). The next is the investigation of the rolling motion of a hollow cylinder using a smartphone's digital compass (Wattanayotin et al., 2017). Of several digital application media used in previous studies, Phyphox is one of the easiest and can be accessed by all students. Phyphox can be used in the classroom or while studying from home during a pandemic as an alternative option when lab facilities are inaccessible.

Kristiyani et al. (2020) applied the Phyphox app to research where the application plays a significant role during the learning process, like ty practicum and discussion activities. Those activities require students to solve the problem presented so that students can improve their learning process skills.

In a study conducted by Sunaryo (2014), this application can form a discussion process and problem-based teaching materials. These two things become supporting aspects in improving students' critical thinking skills. Phyphox can also assist students in recording and analyzing experimental data that can be shared in MS. Excel format.

The Phyphox application as an experimental physics application is 
considered to solve problems in learning physics. It is interesting for students during this learning period, especially the development of student skills. The experiment in this study was successful because the experiment with the Phyphox application had high accuracy. It was necessary to pay attention to the practicum tools used in good condition so that no sensor error was read in the Phyphox application. The most critical factor in using this application is that the sensor must be appropriately read.

So, the advantages of Phyphox For example, in this study, the Phyphox application can be used for physics learning because the sensor results from experimental data are read on a laptop or smartphone screen. The data is displayed graphically and equipped with various innovative features, so Phyphox will be very good and easy to learn.

\section{CONCLUSION AND SUGGESTION}

From the results of research and data processing, the value of the moment of inertia of Phyphox data processing is $4.89 \mathrm{x}$ $10^{-4} \mathrm{~kg} . \mathrm{m} 2$ with a radius of $4 \mathrm{~cm}, 9.82 \times 10^{-4}$ $\mathrm{kg} . \mathrm{m} 2$ with a radius of $5 \mathrm{~cm}, 12.4 \times 10^{-}$ ${ }^{4} \mathrm{~kg} . \mathrm{m} 2$ with a radius of $6 \mathrm{~cm}$. While in manual practicum, namely:4.96x $10^{-4} \mathrm{~kg} \cdot \mathrm{m} 2$, $7.76 \times 10^{-4} \mathrm{~kg} . \mathrm{m} 2$, and $11.6 \times 10^{-4} \mathrm{~kg} . \mathrm{m} 2$. Both methods show almost the same moment of inertia results.

This research can be used as a teacher reference in teaching the topic of moments of inertia in physics learning at school. It is highly recommended for distance learning during the pandemic so that mastery of concepts is maximized and students are also not bored because they tend to have a lot of tasks.

The author suggests that further research can be conducted using other materials with other types of rigid bodies to find the moment of inertia. Additional references on digital application media to assist learning are also needed considering the dynamic development of technology.

\section{REFERENCES}

Alqahtani, M., \& Mohammad, H. (2017). Mobile applications impact on student performance \& satisfaction. The Turkish Online Journal of Educational Technology, 14(4), 102-112.

Ariefka, R., \& Pramudya, Y. (2019). The study of hollow cylinder on inclined plane to determine the cylinder moment of inertia. Journal of Physics: Conference Series, 1170(1), 012081.

Carroll, R., \& Lincoln, J. (2020). Phyphox app in the physics classroom. Phys. Teach., 58(1), 606-607.

Chusni, M. M., Rizaldi, M. F., \& Nurlaela, S. (2018). Penentuan momen inersia benda silinder pejal dengan integral dan tracker. Jurnal Pendidikan Fisika Dan Keilmuan, 4(1), 42-47.

Hara, Y., Hara, K., \& Hayashi, T. (2012). Moment of inertia dependence of vertical axis wind turbines in pulsating winds. International Journal of Rotating Machinery, 2012, 1-12.

Jati, Bambang. (2013). Fisika dasar edisi 2 untuk mahasiswa ilmu eksakta, teknik, dan kedokteran. Andi Press

Jumini, S., \& Muhlisoh, L. (2013). Pengaruh perbedaan panjang poros suatu benda terhadap kecepatan sudut putar. Prosiding Seminar Nasional Sains Dan Pendidikan Sains VIII, 133-138.

Kaps, A., \& Stallmach, F. (2020). Tilting motion \& moment inertia of smartphone. Phys. Teach., 58, 216217.

Kristiyani, Y., Sesunan, F., \& Wahyudi, I. (2020). Pengaruh aplikasi sensor smartphone pada pembelajaran simple harmonic motion berbasis inkuiri terbimbing terhadap peningkatan kemampuan berpikir kritis siswa. 
Jurnal Pendidikan Fisika, 8(2), 138149.

Mulhayatiah, D., Suhendi, H. Y., Zakwandi, R., Dirgantara, Y., \& Ramdani, M. A. (2018). Moment of inertia: development of rotational dynamics kit for physics students recent citations moment of inertia: Conf. Series: Materials Science and Engineering, 012014. https://doi.org/10.1088/1757$899 X / 434 / 1 / 012014$

Nisa, dkk. (2019). Mencari kecepatan dan kecepatan sudut dengan media aplikasi phyphox dalam teknologi pembelajaran fisika. U. Hamka.

Nurfadilah, dkk. (2019). Pengembangan panduan eksperimen fisika menggunakan smarthphone dengan aplikasi phyphox pada materi tumbukan. Jurnal Penelitian Pembelajaran Fisika, 10(2), 101-107.

Olga, S. (2017). Mobile applications for physics studies. In Physical \& Mathematical Edu: Scientific Journal (Vol. 4, Issue 14, pp. 293-298).

Parsons, D. (2016). The future of mobile learning \& implications for education and training. In Transforming Education in the Gulf Region: Emerging Learning Technologies and Innovative Pedagogy for the 21st Century (pp. 217-229). Routledge.

Phyphox. (2020). Phyphox: Physical Phone Experiment. Retrieved August 12, 2021 fromhttps://Phyphox.org/wiki/index.ph p?title=Main_Page.

Pierratos, T., \& Polatoglou, H. M. (2020). Utilizing the phyphox app for measuring kinematics variables with a smartphone. Physics Education, 55(2), $1-7$.

Respati, Y. S., \& Rahardjo, D. T. (2017). Alat penentu indeks bias cairan dibantu dengan sensor ultrasonik berbasis mikrokontroler atmega328. Jurnal Materi dan Pembelajaran Fisika, 7(2),
17-22.

Riswanto, \& Suharno. (2014). Penentuan koefisien momen inersia bola pejal melalui video gerak pada bidang miring dengan fitting data. Pertemuan Ilmiah XXVIII HFI Jateng \& DIY, April, 31-34.

Rivia, N., Kamus, Z., Fisika, M., Pengajar, S., \& Fisika, J. (2016). Pembuatan alat ukur momen inersia benda digital. Pillar of Physics, 8(1), 81-88.

Saputra, W., \& Pramudya, Y. (2019). Pengembangan instrumentasi penentuan kecepatan gerak silinder pejal pada bidang miring dengan menggunakan arduino. Jurnal Pendidikan Informatika Dan Sains, 8(2), 207-215.

Schmelzbach, et al. (2018). Advances in 6c seismology: Applications of combined translational and rotational motion measurements in global and exploration seismology. Geophysics, 83(3), 53-69.

Setyawan, D. N., Sarwanto, \& Aminah, N. S. (2017). Pengembangan pembelajaran berbasis saintifik pada materi dinamika rotasi dan kesetimbangan benda tegar untuk meningkatkan kemampuan berpikir kritis dan komunikasi verbal siswa SMA. Jurnal Penelitian Pembelajaran Fisika, 8(1), 14-25.

Stampfer, C., Heinke, H., \& Staacks, S. (2020). A lab in the pocket. In Nature Reviews Materials, 5(3), 169-170.

Sukariasih, L., Erniwati, Sahara, L., Hariroh, L., \& Fayanto, S. (2019). Studies the use of smartphone sensor for physics learning. International Journal of Scientific and Technology Research, 8(10), 862-870.

Sunaryo. 2014. Pengaruh pembelajaran inkuiri dengan mobile aplication terhadap keterampilan proses sains dan penguasaan konsep ipa siswa 
smp. Jurnal Pendidikan Sains. Online. 2(3), 159-165.

Vieyra, R., Vieyra, C., Jeanjacquot, P., Marti, A., \& Monteiro, M. (2015). Five challenges that use mobile devices to collect and analyze data in physics. Sci. Teach, 82(9), 32-40.

Wattanayotin, P., Puttharugsa, C., \& Khemmani, S. (2017). Investigation of the rolling motion of a hollow cylinder using a smartphone's digital compass. Physics Education, 52(4), 045009.

Yusuf, K. (2015). Penentuan koefisien momen inersia dengan video analisis. Prosiding Seminar Nasional Fisika Dan Pendidikan Fisika (SNFPF) Ke-6, 6(1), 174-178. 